RESEARCH ARTICLE

\title{
Tussock Moths: A Bio-indicator of Disturbed Ecosystems
}

\section{Balaji R K $\mathbf{~}^{1}$, Chitra $\mathbf{N}^{1 *}$, Arulprakash $\mathbf{R}^{2}$, Mohankumar $\mathbf{S}^{3}$ and Kumaraperumal $\mathbf{R}^{4}$}

${ }^{1 *}$ Department of Agricultural Entomology, Tamil Nadu Agricultural University, Coimbatore-641003

${ }^{2}$ Department of Seed Science and Technology, Tamil Nadu Agricultural University, Coimbatore-641003

${ }^{3}$ Centre for Plant Molecular Biology and Biotechnology, Tamil Nadu Agricultural University, Coimbatore-641003

${ }^{4}$ Department of Remote Sensing and Geographical Information System, Tamil Nadu Agricultural University, Coimbatore - 641003.

\begin{abstract}
In the wake of invasive species and climate change, sub-family Lymantriinae a neglected group was chosen to evaluate and consider as bio-indicator of the disturbed ecosystem with anthropogenic activities. In the present study, moth collections were carried out through a light trap in the plains at the foot hills of the Nilgiris and hilly regions of lower Pulney hills. The hilly region was more abundant with 260 individuals of 18 species from 12 genera under 5 tribes than the plains with 87 individuals of 14 species from 10 genera under 4 tribes. The dominant Lymantriid fauna were distinctly different for both regions. Plains were dominated by Aroa simplex attributed to prevalence of Lantana camera and hilly regions dominated by Perina nuda on Artocarpus heterophyllus intercropped in coffee plantations. The alpha diversity analysis also indicated that the hilly region was species-rich than the plains with more anthropogenic activities through Shannon Weiner Diversity index, Simpson's Diversity index, Margalef Index of Species Richness, Equitability J Evenness Index, Jaccard and Sorensen Indices of Similarity.
\end{abstract}

Keywords: Lymantriinae; Biological indicator; The Western Ghats; Plains; Hilly region.

\section{INTRODUCTION}

The Western Ghats, one of the oldest mountain ranges of India is among the eight hotspots of biological diversity in the world with high endemism (Myers et al., 2000). Though the Western Ghats is a UNESCO World Heritage Site (UNESCO, 2012), it is classified under the area of "significant concern" under the International Union for Conservation of Nature (World Heritage Outlook, 2020). The Western Ghats is also known as the Great Escarpment (Kale, 2010). The area under the Western Ghats comprises $1,80,000 \mathrm{~km}^{2}$ which is almost six per cent of the Indian land mass and more than 30 per cent of the Indian biodiversity (WWF, 2021). Endowed with rich biodiversity, the Western Ghats has 229 plant species, 31 mammal species, 15 bird species, 43 amphibian species, 5 reptile species and 1 fish species under the threatened category. Of these 129 species are classified as vulnerable, 145 species as endangered and 51 as critically endangered. However, the data and status of the insects in the Western Ghats are poorly documented. Except for the studies on butterfly fauna from Pulney hills (Evans, 1910; Ugarte and Rodricks, 1963; Shahabuddin, 1997; Ghorpade and Kunte, 2010) other insect faunal studies remain to be explored.

Insects contribute to most of the tropical forest biomass (Fatimah and Catherine, 2002). Insects, a megadiverse taxon of species-rich especially in the tropics have always been biological indicators of any given area (Gurule and Nikam, 2013). Evaluation of total species richness would be laborious and time-consuming (Kendrick, 2002). Among insects, moths have been reported as prominent indicator of ecosystem's diversity (Gurule and Nikam, 2013). Horticultural plantations have spread over the Lower Pulneys, which necessitates moth fauna studies in the wake of invasive species and climate change.

Family Liparidae, a neglected group (Swinhoe, 1923), has undergone dynamic hierarchical changes in recent years and is currently classified as subfamily Lymantriinae under Erebidae (Order: Lepidoptera) (Zahiri et al., 2011; Zahiri et al., 2012). The Lymantriid moths are referred as 'tussock moths' for their striking tuft of hairs and are poorly studied moths of Erebidae. Lymantriinae comprises 2,500 species under 360 genera world over (van Nieukerken et al., 2011) and is represented by 173 species and 28 genera in British India (inclusive of the geographical area of Myanmar, Bhutan and Sri Lanka) (Hampson, 1893). Tussock moths are often minor pests of agri-horticultural and forest tree species in India (McManus et al., 1992). An attempt was taken to evaluate and consider Lymantriinae as biological indicator of the ecosystem 
with the anthropogenic activities in the plains region of foothills of the Nilgiris viz., Mettupalayam, Coimbatore and the hilly region of the Lower Pulney hills of the Western Ghats.

\section{MATERIAL AND METHODS}

Plains at foot hills of the Nilgiris and hilly regions of Lower Pulney hills were selected to survey from the Leeward side of Western Ghats. Plain regions comprised areas in and around Anaikatti, Mettupalayam, Pollachi, Ramanathapuram, Siruvani, and Tamil Nadu Agricultural University (TNAU), while hilly regions included areas in and around Kodaikanal, Perumalmalai, Thadiyankudisai and Thandikudi. The moths were collected with moth sheet trap from 2018 to 2021 . The collected specimens were relaxed, set, labelled, preserved and deposited in the TNAU Insect Museum, Department of Agricultural Entomology, TNAU, Coimbatore. Identification of Lymantriinae moths was carried out with standard references Hampson (1893), Holloway (1999), Schintlmeister (2004) and with reference collections of TNAU Insect Museum, Department of Agricultural Entomology, TNAU, Coimbatore.

The relative abundance and diversity analysis viz., Shannon-Wiener Diversity Index (Shannon and Weaver, 1949), Simpson's Diversity Index (Simpson, 1949), Margalef Index of Species Richness (Margalef, 1958) and Equitability J Evenness Index (Magurran, 1985) were calculated using the biodiversity calculator (https://www.alyoung.com/ labs/biodiversity_calculator.html). Similarity indices viz., Jaccard Index (Jaccard, 1912) and Sorensen Index (Sorensen, 1948) were calculated manually to compare the similarity of tussock moth fauna in the plains and hilly region.

\section{RESULTS AND DISCUSSION}

\section{Relative Abundance}

A total of 87 and 260 individuals from plains at foot hills of the Nilgiris and hilly region of Lower Pulney hills were documented respectively. In plains, 14 species under 10 genera of 4 tribes were observed and in the case of Lower Pulney Hills the tussock moth assemblage included 18 species from 12 genera and 5 tribes (Table 1).

Table 1. Jaccard and Sorensen similarity indices of Lymantriinae between plains and hills

\begin{tabular}{lc}
\hline \multicolumn{1}{c}{ Similarity Indices } & Index value \\
\hline Jaccard Index of Similarity & 0.3333 \\
Sorensen Index of Similarity & 0.5000 \\
\hline
\end{tabular}

There was a distinct difference in the dominance of the moth species between the two regions studied. In the plain region, Aroa simplex (28.73\%) was the most abundant, followed by Euproctis fraterna and
Olene mendosa (11.49\% each). In the hilly region, Perina nuda (21.54\%) was the most abundant followed by Lymantria todara (19.61\%) and Nygmia icilia (15.00\%) (Figure 1). The abundance of $A$. simplex could be attributed to its continued survival on Lantana camera, a common ornamental shrub in many landscape gardens and wild while, the abundance of $P$. nuda could be due to arboreal flora of Moraceae with Artocarpus heterophyllus (Jackfruit) as the prevalent host intercropped in coffee plantations (Robinson, 2010).

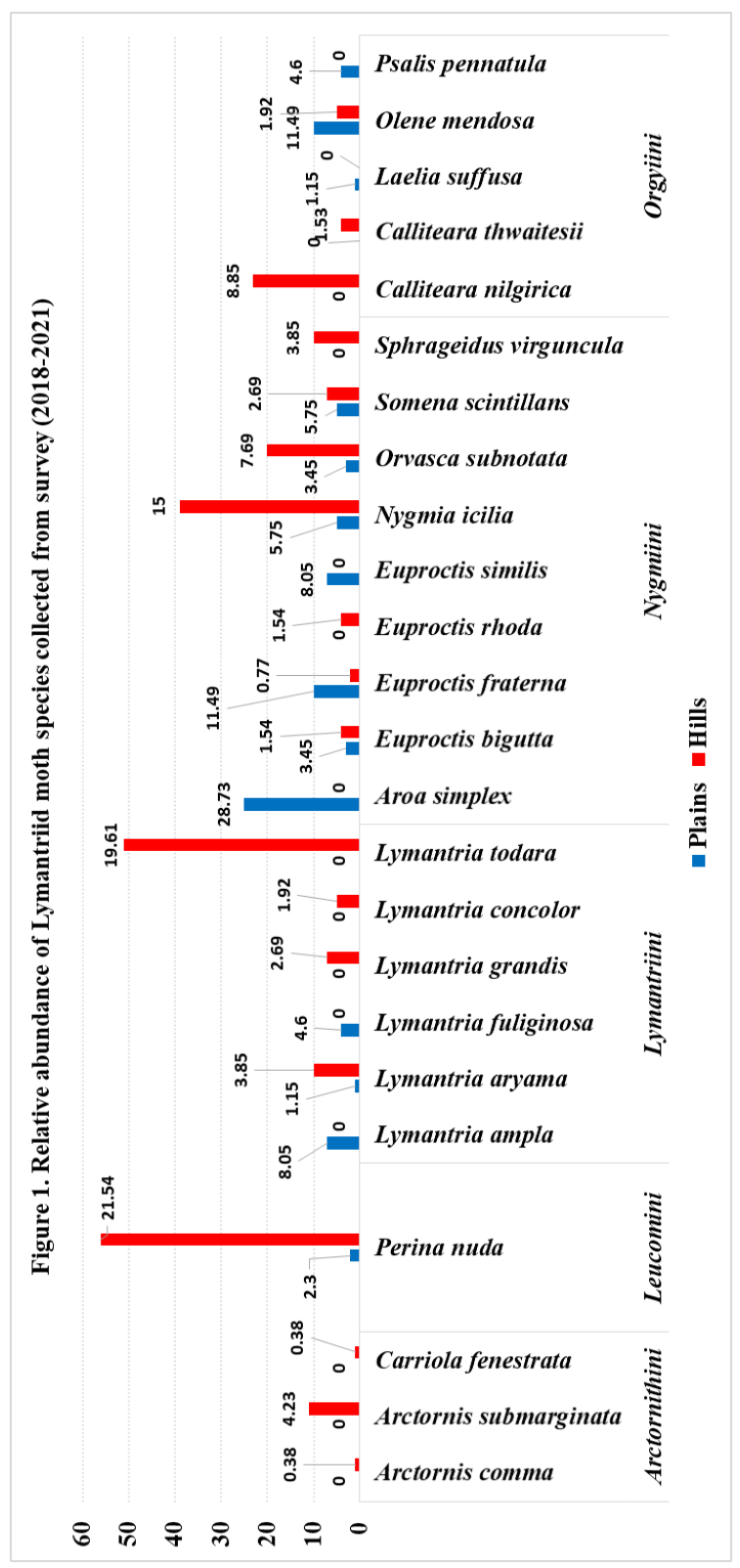

\section{Alpha diversity indices}

The Shannon Diversity Index was higher for the hilly region (2.3510) than the plains (2.2940). The Simpson's Diversity Index was higher for the hilly region $(0.8745)$ than the plains $(0.8741)$. The Simpson's Diversity Index and Margalef Index of Species Richness values were almost invariable for 
both hilly regions (0.8745 and 3.0570) and plain regions (0.8741 and 2.9110). The plain region had higher Equitability J Evenness Index value than the hilly region (0.8694 and 0.8132) (Figure 2).

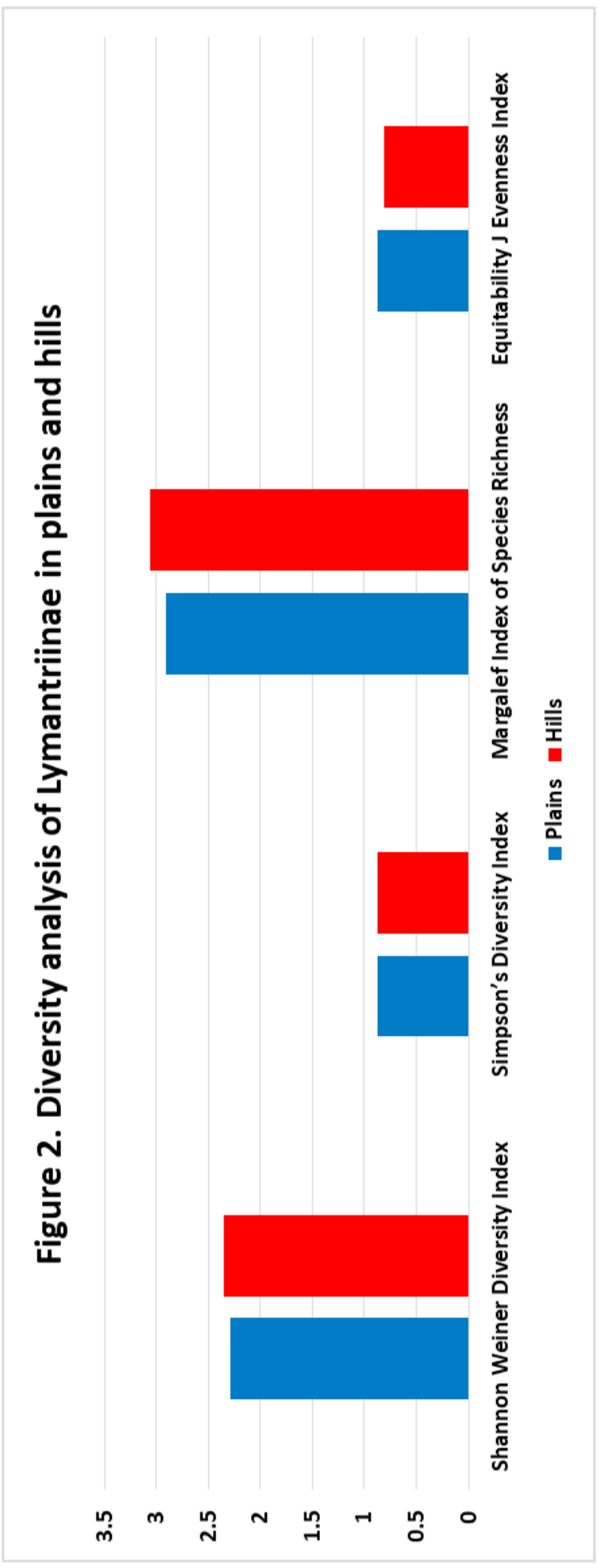

\section{Similarity indices}

There were 8 species from 7 genera and 4 tribes common to both the regions viz., Perina nuda (Leucomini), Lymantria aryama, (Lymantriini), Euproctis bigutta, E. fraterna, Nygmia icilia, Orvasca subnotata, Somena scintillans, (Nygmiini) and
Olene mendosa (Orgyiini). Similarity index values of Jaccard and Sorensen were 0.3333 and 0.5000 , respectively. It was observed that the proportion of common species was better represented in Jaccard similarity index than Sorensen similarity index (Table 1.).

\section{CONCLUSION}

Most Lymantriid moths having forest tree species as hosts might have contributed to higher abundance and species number in the hilly region than in plains. Wilson et al (2018) reported that light pollution in urban areas significantly impacted moth abundance. It is suspected that light pollution in the plains might have diminished the abundance and species number.

Shannon Weiner Diversity Index has been frequently used among various alpha diversity indices for its evident differentiation of diversity in an ecosystem and this has been reported (Ramya et al., 2021).

The alpha diversity indices viz., Shannon Weiner Diversity Index, Simpson's Diversity Index, Margalef Index of Species Richness and Equitability $J$ Evenness Index rely on quantitative characters to access diversity. In contrast, similarity indices Jaccard and Sorensen rely on qualitative data (presence-absence data) to access diversity (Jongman et al., 1987). Jaccard and Sorensen similarity indices represent the same trend in the present study. Yet, Sorensen index values are more remarkable owing to dividing the total number of common species by the average number of species in two study areas, unlike the Jaccard index, which divides the total number of common species by the total number of species in two study area (Jongman et al., 1987).

From this study, it is proposed that Lymantriinae could be considered as biological indicator of the ecosystem with anthropogenic activities. Swinhoe as early as 1923 had stated that Lymantriinae (then Liparidae) were a neglected group of Lepidoptera. This trend has been prevailing for over a century and is finding light in recent years because of changes in taxonomical hierarchy and attainment of certain research plateau in other families of Lepidoptera. From the above stated scenario, this study might add fuel to the ignited spark.

\section{Funding and Acknowledgment}

The study was part of the PhD thesis of the first author (RKB), and NC as advisor. The financial assistance received in the form of Scholarship from Jawaharlal Nehru Memorial Fund is acknowledged.

\section{Consent for publication}

All the authors agreed to publish the content. 


\section{Competing interests}

There were no conflict of interest in publication of this content

\section{REFERENCES}

Evans, W. H. 1910. A List of the Butterflies of the Palni Hills with descriptions of two new species. J. Bom. Nat. Hist. Soc., 20: 380-392.

Fatimah, A. and A. K. Catherine. 2002. The larger moths (Lepidoptera: Heterocera) of the Crocker Range National Park, Sabah: A preliminary checklist. ASEAN Rev. Bio. Env. Cons. (ARBEC), 1-14.

Ghorpade, K. and K. Kunte. 2010. Butterflies (Lepidoptera-Rhopalocera) of the Palni Hills, southern Western Ghats in peninsular India: an updated review, with an appreciation of Brigadier W H Evans. Colemania, 23: 1-19.

Gurule, S. A. and S. M. Nikam. 2013. The moths (Lepidoptera: Heterocera) of northern Maharashtra: A preliminary checklist. J. Threat. Taxa, 5(12): 4693-4713.

Hampson, G. F. 1893. Moths. In: The Fauna of British India, including Ceylon and Burma, Blandford W T (edr.). Taylor and Francis, London, 527p.

Holloway, J. D. 1999. The Moths of Borneo (Part 5): Family Lyamatriidae. Mal. Nat. J., 53: 1-188.

Jaccard, P. 1912. The distribution of the flora in the alpine zone. New Phyt., 11(2): 37-50.

Jongman, R. H. G., Ter Braak, C. F. J. and O. F. R. van Tongeren. 1987. Data Analysis in Community and Landscape Ecology. Wageningen: Pudoc, 299p.

Kale, V. S. 2010. The Western Ghat: The Great Escarpment of India. Piotr M (edr.). In: Geomorphological Landscapes of the World. Springer, London, 257264.

Magurran, A. E. 1985. The diversity of Macrolepidoptera in two contrasting woodland habitats at Banagher, Northern Ireland. Proceedings of the Royal Irish Academy. Section B: Biological, Geological, and Chemical Science, 121-132.

Margalef, R. 1958. Information theory in biology. Gen. Sys. Yearbook, 3:36-71.

McManus, M., Schneeberger, N., Reardon, R. and G. Mason. 1992. Forest Insect and Disease Leaflet 162: Gypsy Moth. US Department of Agriculture Forest Service, Washington, DC, 19p.

Myers, N., Mittermeier, R. A., Mittermeier, C. G., da Fonseca, G. A. B. and J. Kent. 2000. Biodiversity hotspots for conservation priorities. Nature, 403: 853-858.

Ramya, R. S., Kumar, M. G., Ranjith, M. and D. R. Bajya. 2021. Arthropod diversity indices in floricultural ecosystem: Which fares better?. Ind. J. Agri. Sci., 91(3):340-343

Robinson, G. S., Ackery, P. R., Kitching, I. J., Beccaloni, G. W. and L. M. Hernandez. 2010. HOSTS - A Database of the World's Lepidopteran Hostplants.
Natural History Museum, London. http://www.nhm. ac.uk/hosts. (Accessed: 31-08-2021).

Schintlmeister, A. 2004. The taxonomy of the genus Lymantria HUBNER, [1819] (Lepidoptera: Lymantriidae). Quadrifina, 7(1): 1-248.

Shahabuddin, G. 1997. Preliminary observations on the role of coffee plantations as avifaunal refuges in the Palni Hills of the Western Ghats. J. Bom. Nat. Hist. Soc., 94: 10-21.

Shannon, C. E. and W. Weaver. 1949. The Mathematical Theory of Communications. Vol. 96. Urbana, IL: University of Illinois Press.

Simpson, E. H. 1949. Measurement of diversity. Nature, 163(4148): 688-688.

Sorensen, T. A. 1948. A method of establishing groups of equal amplitude in plant sociology based on similarity of species content, and its application to analyses of the vegetation on Danish commons. Kong. Dan. Viden. Sels. Bio. Skr., 5: 1-34.

Swinhoe. C. C. 1923. VI.A revision of the genera of the family Liparidae. Ann. Mag. Nat. Hist., 11(61): 47-97.

Ugarte, E. and L. Rodricks. 1963. Butterflies of the Palni Hills: a complementary list. J. Bom. Nat. Hist. Soc., 57: 270-277.

UNESCO. 2012. https://whc.unesco.org/en/list/1342 (Accessed on: 31-08-2021)

van Nieukerken, E. J., Kaila, L., Kitching, I. J., Kristensen, N. P., Lees, D. C., Minet, J., Mitter, C., Mutanen, M., Reiger, J. C., Simonsen, T. J. and N. Wahlberg. 2011. Order Lepidoptera Linnaeus, 1758. Edited by Z Q Zhang. Vol. 3148, Animal biodiversity, an outline of higher-level classification and survey of taxonomic richness: Zootaxa, 212-221.

Wilson, J. F., Baker, D., Cheney, J., Cook, M., Ellis, M., Freestone, R., Gardner, D., Geen, G., Hemming, R., Hodgers, D., Howarth, S., Jupp, A., Lowe, N., Orridge, S., Shaw, M., Smith, B., Turner, A. and H. Youth. 2018. A role for artificial night-time lighting in long-term changes in populations of 100 widespread macro-moths in UK and Ireland: a citizen-science study. J. Ins. Cons., 22(2): 189196.

World Heritage Outlook. 2020. https://www. worldheritageoutlook.iucn.org/explore-sites/ wdpaid/555547990. (Accessed on: 31-08-2021)

WWF.2021.https://www.wwfindia.org/about_wwf/ critical_regions/western_ghats2/about_the _ western_ghats/ (Accessed on: 31-08-2021)

Zahiri, R., Holloway, J. D., Kitching, I. J., Lafontaine, J. D., Mutanen, M. and N. Wahlberg. 2012. Molecular phylogenetics of Erebidae (Lepidoptera, Noctuoidea). Syst. Ent., 37(1): 102-124.

Zahiri, R., Kitching, I. J., Lafontaine, J. D., Mutanen, M., Kaila, L., Holloway, J. D. and N. Wahlberg. 2011. A new molecular phylogeny offers hope for a stable family level classification of the Noctuoidea (Lepidoptera). Zoo. Scri., 40(2): 158-173. 